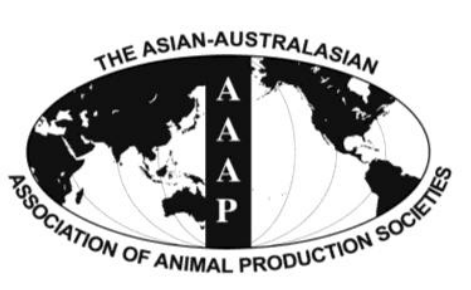

Open Access

Asian Australas. J. Anim. Sci.

Vol. 27, No. 8 : 1150-1156 August 2014

http://dx.doi.org/10.5713/ajas.2013.13828

www.ajas.info

pISSN 1011-2367 elSSN 1976-5517

\title{
Effects of L-proline on the Growth Performance, and Blood Parameters in Weaned Lipopolysaccharide (LPS)-challenged Pigs
}

\author{
Ping Kang ${ }^{1}$, Lili Zhang ${ }^{1}$, Yongqing Hou ${ }^{1, *}$, Binying Ding ${ }^{1}$, Dan Yi ${ }^{1}$, Lei Wang ${ }^{1}$, \\ Huiling $\mathrm{Zhu}^{1}$, Yulan Liu ${ }^{1}$, Yulong $\mathrm{Yin}^{1,2}$, and Guoyao $\mathrm{Wu}^{3}$ \\ ${ }^{1}$ Hubei key Laboratory of Animal Nutrition and Feed Science, Wuhan Polytechnic University, Wuhan 430023, China
}

\begin{abstract}
This trail was conducted to study the effect of L-proline on the growth performance, and blood parameter in the weaned lipopolysaccharide (LPS)-challenged pigs. Thirty six pigs $(9.13 \pm 0.85 \mathrm{~kg})$ were assigned randomly to dietary treatments in a $2 \times 3$ factorial arrangement in a 20-d growth assay. Factors were intraperitoneal injection with saline or LPS, and three dietary L-proline supplement levels $(0 \%, 0.5 \%$, or $1.0 \%)$. On d 10, blood samples were collected at $3 \mathrm{~h}$ after LPS (100 $\mu \mathrm{g}$ LPS $/ \mathrm{kg}$ body weight [BW]) or saline injection. On d 20 of the trial, all pigs were orally administrated D-xylose $(0.1 \mathrm{~g} / \mathrm{kg} \mathrm{BW})$ at $2 \mathrm{~h}$, and blood samples were collected at $3 \mathrm{~h}$ after LPS or saline injection. As a result, dietary supplementation with $0.5 \%$ proline had a tendency to increase average daily gain (ADG) in piglets during $\mathrm{d} 10$ to $20(\mathrm{p}=0.088)$. Without LPS challenge, dietary supplementation with $1.0 \%$ proline had no effect on growth hormone $(\mathrm{GH})$ concentrations on d $10(\mathrm{p}>0.05)$, but decreased it after LPS challenge $(\mathrm{p}<0.05)$. There was LPS challengexproline interaction for GH concentrations on d $10(\mathrm{p}<0.05)$. Dietary supplementation with $1.0 \%$ proline decreased glucagon concentration on $\mathrm{d}$ 10 after LPS challenge $(\mathrm{p}<0.05)$. In addition, dietary supplementation with proline increased superoxide dismutase (SOD) activity significantly on d 10 and $20(\mathrm{p}<0.05)$, and $1.0 \%$ proline increased heat shock proteins-70 concentration on $\mathrm{d} 10(\mathrm{p}<0.05)$. Moreover, proline supplementation increased diamine oxidase (DAO) concentrations after LPS challenge $(\mathrm{p}<0.05)$. There was LPS challengexproline interaction for DAO ( $\mathrm{p}<0.05)$. Furthermore, dietary supplementation with $1.0 \%$ proline increased the D-xylose level when no LPS challenge $(p<0.05)$. These results indicate that proline supplementation could improve growth performance, increase SOD activities, and has a positive effect on the gastrointestinal tract digestibility in early weaned pigs. (Key Words: L-proline, Growth Performance, Blood Parameters, Gastrointestinal Tract Digestibility, Early Weaned Pigs, Lipopolysaccharide)
\end{abstract}

\section{INTRODUCTION}

Proline is one of the most abundant amino acid in sow's colostrum and milk. Previous studies have shown that proline is an indispensable amino acid in the diets of $2.5-\mathrm{kg}$ pigs (Ball et al., 1986) and young chicks (Baker, 1977). Young pigs have a limited ability to synthesize proline from arginine, glutamine or glutamate in the small intestine (Wu et al., 1996), thus, dietary supplementation with proline

\footnotetext{
* Corresponding Author: Yongqing Hou. Tel: +86-27-83956175, Fax: +86-27-83956175, E-mail: houyq777@yahoo.com.cn

${ }^{2}$ Institute of Subtropical Agriculture, the Chinese Academy of Sciences, Changsha 410125, China.

3 Department of Animal Science, Texas A \& M University, College Station, TX 77843, USA.

Submitted Dec. 14, 2013; Revised Mar. 13, 2014; Accepted Apr. 22, 2014
}

could play an important role for the weaned piglets.

There has been growing interest in proline metabolism and nutrition over the past decade (Phang and Liu, 2012). Growing evidence shows that proline plays an important role in differentiation and multiple biochemical and physiological processes in cells (Phang and Liu, 2012), as well as conceptus growth and development (Wu et al., 2008). Wu (1997) reported that proline was a major dietary precursor for de novo synthesis of arginine by the pig small intestine, suggesting that proline could spare a portion of the arginine requirement. Bertolo et al. (2003) concluded that the piglet could not synthesize sufficient proline to maintain its concentrations in plasma, and arginine synthesized from proline was also diminished as a result of gut atrophy during parenteral feeding. In addition, proline can serve as a major amino acid for the synthesis of 
polyamines in the small intestine ( $\mathrm{Wu}$ et al., 2000). Therefore, proline could play an essential role for the weaned piglets. Previous study has shown that L-proline can improve small-intestinal morphology in the weanling piglet ( $\mathrm{Wu}$ et al., 2011). However, the underlying mechanisms are unknown.

Newly weaned piglets are highly susceptible to various stressors. Because lipopolysaccharide (LPS) has been used as a tool to induce sickness behavior in the pigs (Lay et al., 2011), we hypothesized that proline could improve growth performance and relieve LPS challenge by reducing intestinal oxidative stress, stimulating some growth factors or hormones secretion, and improving the digestibility in piglets. In modern animal improvement, blood biochemical characteristic is an important indicator (El Darawany and Farghaly, 1999), accordingly, in this study, the growth performance and selected blood metabolites were measured to test our hypothesis.

\section{MATERIAL AND METHODS}

The animal use protocol for this research was approved by the Animal Care and Use Committee of Hubei Province. A total of thirty-six healthy crossbred (Duroc $x$ Landracex Yorkshire) piglets $(9.13 \pm 0.85 \mathrm{~kg})$ were weaned at $21 \pm 3 \mathrm{~d}$ of age and used in a 20-day feeding trail. During d 0 to 10 of feeding trial, pigs were assigned randomly to three diet treatments, i) basal diet $(0 \%$ proline [PRO]), ii) basal diet supplemented with $0.5 \%$ PRO, and iii) basal diet supplemented with $1.0 \%$ PRO. Each treatment had six replicates and each replicate comprised two pigs. On d 10, two pigs in each replicate were separated and housed individually, and one pig was injected intraperitoneally with saline (-LPS), and the other pig was injected intraperitoneally with LPS (+LPS). Therefore, pigs were assigned in a $2 \times 3$ factorial arrangement during d 10 to 20 , each treatment had six replicates and each replicate comprised one pig. On d 10 and 20, pigs were administrated with intraperitoneal injections with either $100 \mu \mathrm{g} \mathrm{LPS} / \mathrm{kg}$ body weight $(\mathrm{BW})$ or an equivalent volume of sterile saline. On d 20, D-xylose was given via i.g. gavage to all pigs at the dosage of $0.1 \mathrm{~g} / \mathrm{kg} \mathrm{BW}$ (infused with $10 \% \mathrm{D}$-xylose at 1 $\mathrm{mL} / \mathrm{kg} \mathrm{BW}), 2 \mathrm{~h}$ after LPS challenge or saline injection. The basal diet was prepared to meet or exceed NRC (1998) nutrient requirement (Table 1), alanine was used to make the treatments isonitrogenous.

\section{Performance}

Feed intake was measured every day during the entire experimental time, and pigs were weighed on $\mathrm{d} 0,10$, and 20 to calculate average daily gain (ADG), average daily feed intake (ADFI), and feed:gain ration $(\mathrm{F} / \mathrm{G})$.
Table 1. The composition and nutrient contents of basal diet (air dry basis)

\begin{tabular}{|c|c|}
\hline Item & Content \\
\hline \multicolumn{2}{|l|}{ Ingredients (\%) } \\
\hline Corn & 61.88 \\
\hline Soybean meal & 21.98 \\
\hline Wheat middling & 4.00 \\
\hline Fish meal & 3.00 \\
\hline Dried whey & 3.00 \\
\hline Soy protein concentrate & 1.50 \\
\hline $\mathrm{CaHPO}_{4}$ & 1.25 \\
\hline $\operatorname{Premix}^{1}$ & 1.00 \\
\hline Limestone & 0.69 \\
\hline Soy oil & 0.50 \\
\hline Acidifier & 0.30 \\
\hline $\mathrm{NaCl}$ & 0.30 \\
\hline L-lysine $\cdot \mathrm{HCl}$ & 0.25 \\
\hline Choline chloride & 0.20 \\
\hline Mould inhibitor & 0.10 \\
\hline DL-methionine & 0.05 \\
\hline Total & 100 \\
\hline \multicolumn{2}{|l|}{ Nutrient levels } \\
\hline $\mathrm{DE}(\mathrm{MJ} / \mathrm{kg})$ & 14.22 \\
\hline $\mathrm{CP}(\%)$ & 20.9 \\
\hline Lys (\%) & 1.15 \\
\hline Met $(\%)$ & 0.30 \\
\hline Met+cys $(\%)$ & 0.65 \\
\hline $\operatorname{Thr}(\%)$ & 0.74 \\
\hline $\operatorname{Trp}(\%)$ & 0.21 \\
\hline $\mathrm{Ca}(\%)$ & 0.70 \\
\hline $\mathrm{P}(\%)$ & 0.60 \\
\hline Available phosphorus (\%) & 0.32 \\
\hline $\mathrm{NaCl}(\%)$ & 0.38 \\
\hline Proline (\%) & 1.44 \\
\hline Alanine $(\%)$ & 0.47 \\
\hline
\end{tabular}

DE, digestible energy; $\mathrm{CP}$, crude protein.

${ }^{1}$ The premix provides for a $\mathrm{kg}$ of feed: $\mathrm{Fe}$ (as ferrous of sulfate), $100 \mathrm{mg}$; $\mathrm{Cu}$ (as copper sulfate), $150 \mathrm{mg}$; $\mathrm{Mn}$ (as manganese sulfate), $40 \mathrm{mg} ; \mathrm{Zn}$ (as zinc sulfate), $100 \mathrm{mg}$; I, $0.5 \mathrm{mg}$; Se (as sodium selenite), $0.3 \mathrm{mg}$; vit A, $10,800 \mathrm{IU}$; vit $\mathrm{D}_{3}, 4,000 \mathrm{IU}$; vit $\mathrm{E}, 40 \mathrm{IU}$; vit $\mathrm{K}_{3}, 4 \mathrm{mg}$; vit $\mathrm{B}_{1}$ (thiamine), $6 \mathrm{mg}$; vit $\mathrm{B}_{2}$ (riboflavin), $12 \mathrm{mg}$; vit $\mathrm{B}_{6}$ (pyridoxin), $6 \mathrm{mg}$; vit $\mathrm{B}_{12}$ (cobalamin), $0.05 \mathrm{mg}$; biotin, $0.2 \mathrm{mg}$; folic acid, $2 \mathrm{mg}$; niacin, $50 \mathrm{mg}$; D-calcium pantothenate, $25 \mathrm{mg}$.

\section{Blood collection}

Blood samples were collected via the jugular vein into $10 \mathrm{~mL}$ heparinized vacuum tubes at $3 \mathrm{~h}$ after LPS or saline injection on d 10 and 20 , and then centrifuged at $3,000 \times \mathrm{g}$ for $10 \mathrm{~min}$ to collect plasma. Plasma was frozen at $-80^{\circ} \mathrm{C}$ until analysis. All blood samples were analyzed in duplicate.

\section{Chemical analysis}

Epidermal growth factor, insulin, nitric oxide, NO synthase, growth hormone and insulin-like growth factor 1 assay: Plasma concentrations of epidermal growth factor 
(EGF), and insulin (INS) were measured with radioimmunoassay kits (Beijing SINO-UK Institute of Biological Technology, Beijing, China). The detection limits for EGF and INS assays were $0.1 \mathrm{ng} / \mathrm{L}$ and $2 \mu \mathrm{U} / \mathrm{mL}$, respectively. The intra- and inter- assay coefficients of variation were $5 \%$ and $10 \%$ for EGF, $10 \%$ and $15 \%$ for INS, respectively. Plasma concentrations of nitrite plus nitrate nitric oxide (NO), total NO synthase (NOS), growth hormone (GH), and insulin-like growth factor (IGF)-I were measured, as we previously described (Kang et al., 2010).

Superoxide dismutase, malondialdehyde, and catalase assays: Plasma concentrations of catalase (CAT), malondialdehyde (MDA), and superoxide dismutase (SOD) were measured using commercial kits (Nanjing Jiancheng Biotechnology Co, Ltd, Nanjing, China). The SOD activity assay is based on nitroblue tetrazolium (NBT) which can be reduced to blue formazan by $\mathrm{O}^{2-}$, and has a strong absorbance at $550 \mathrm{~nm}$. One unit (U) of SOD is defined as the amount that inhibits the NBT reduction by $50 \%$ per minute in $1 \mathrm{~mL}$ plasma. The calculated SOD activity is expressed as $\mathrm{U} / \mathrm{mL}$ plasma. Total CAT activity was determined as the consumption of $\mathrm{H}_{2} \mathrm{O}_{2}$ measured at 405 $\mathrm{nm}$ for $1 \mathrm{~min}$ at $37^{\circ} \mathrm{C}$. One unit (U) of CAT is defined as 1 $\mathrm{mL}$ plasma that breaks down $1 \mu \mathrm{mol} \mathrm{H}_{2} \mathrm{O}_{2}$ per second at $37^{\circ} \mathrm{C}$. The calculated CAT activity is expressed as $\mathrm{U} / \mathrm{mL}$ plasma. The method for measuring MDA is based on the reaction with thiobarbituric acid (TBA), the absorbance of the supernatant fluid was recorded at $535 \mathrm{~nm}$. Malondialdehyde results are expressed as $\mathrm{nmol} / \mathrm{mL}$ plasma (Buege and Aust, 1978).

Plasma D-xylose content: The D-xylose absorption test was carried out according to the method described by Mansoori et al. (2009). Briefly, $50 \mu \mathrm{L}$ of the collected plasma was added to $5 \mathrm{~mL}$ of phloroglucinol (Sigma Chemical Inc., St. Louis, MO, USA) colour reagent solution and heated at $100^{\circ} \mathrm{C}$ for $4 \mathrm{~min}$. The samples were allowed to cool to room temperature in a water bath. D-xylose standard solutions were prepared by dissolving D-xylose in saturated benzoic acid (prepared in deionized water) to obtain $0,0.7,1.3,2.6 \mathrm{mmol} / \mathrm{L}$. They were added to colour reagent solution as described for samples. The absorbance of all samples and standard solutions were measured, using a spectrophotometer (Model 6100, Jenway LTD., Felsted, Dunmow, CM6 3LB, Essex, England, UK), set at $554 \mathrm{~nm}$. The standard solution of $0 \mathrm{mmol} / \mathrm{L}$ D-xylose was considered as blank.

Diamine oxidase assay: Diamine oxidase (DAO) activity in plasma was determined using spectrophotometry as described by Hosoda et al. (1989). The assay mixture (3.8 mL) contained $3 \mathrm{~mL}$ of phosphate buffer $(0.2 \mathrm{M}, \mathrm{pH}$ 7.2), $0.1 \mathrm{~mL}(0.004 \%)$ of horseradish peroxidase solution (Sigma Chemicals), $0.1 \mathrm{~mL}$ of $o$-dianisidine-methanol solution $(0.5 \%$ of $o$-dianisidine [Sigma Chemicals] in methanol), $0.5 \mathrm{~mL}$ of plasma, and $0.1 \mathrm{~mL}$ of substrate solution $(0.175 \%$ of cadaverine dihydrochloride, Sigma Chemicals). This mixture was incubated for $30 \mathrm{~min}$ at $37^{\circ} \mathrm{C}$, and absorbance at $436 \mathrm{~nm}$ was measured to indicate DAO activity.

Heat shock proteins-70 and $\alpha 1-A G P$ assay: Heat shock proteins-70 (HSP-70) and $\alpha 1$-acid glycoprotein ( $\alpha 1$-AGP) in plasma were determined by using commercially available enzyme-linked immunosorbent assays (ELISA) kits (Beijing SINO-UK Institute of Biological Technology, China). Optical density values were read at $450 \mathrm{~nm}$. The intra- and inter-assay coefficients of variation were $<10 \%$. The detection limits for HSP-70 and $\alpha 1$-AGP were 0.1 $\mathrm{ng} / \mathrm{mL}$ and $1.0 \mu \mathrm{g} / \mathrm{mL}$, respectively.

\section{Statistical analysis}

Data were analyzed by analysis of variance using the general linear model procedures of SAS (SAS Inst. Inc., Cary, NC, USA) appropriate for a factorial arrangement of treatments with completely randomized design with $2 \times 3$ factorial arrangement. The statistical model included the effects of challenge (saline or LPS), proline (0, 0.5, and $1.0 \%$ ), and their interaction. The experimental unit for the performance during d 0 to 10 was the two pigs, and other statistical procedures was the individual pig. A repeated measures for the blood parameters was analyzed for the responses following LPS challenge. The normality and constant variance for experimental data were tested by the Levene's test (Wei et al., 2012). If data did not have homogenous variance, they underwent logarithm transformation to meet the necessary assumptions of analysis of variance (Wei et al., 2012). Differences among treatment means were determined by the Duncan's multiple range test. The statistical significance level for all analyses was set at $\mathrm{p}<0.05$, and $0.05<\mathrm{p}<0.10$ were discussed as trends.

\section{RESULTS}

\section{Growth performance of weanling pigs}

Data on growth performance of weanling pigs were shown in Table 2 and 3. Dietary supplementation with proline had no effect on ADG, ADFI, and F/G during d 0 to10 ( $p>0.05)$. LPS challenge could decrease ADG and ADFI $(\mathrm{p}<0.05)$, however, dietary supplementation with $0.5 \%$ proline had a tendency to increase ADG in both saline treated and LPS-challenged pigs during d 10 to 20 ( $p<0.1)$. There was no LPS challengexproline interaction for ADG, ADFI, and gain/feed during d 10 to 20 ( $\mathrm{p}>0.05)$.

\section{Plasma growth factor and hormone concentrations}

As shown in Table 4, LPS challenge could decrease 
Table 2. Effects of L-proline supplementation on growth performance of piglets during $0-10 \mathrm{~d}^{1}$

\begin{tabular}{|c|c|c|c|c|c|}
\hline Items & $0 \%$ PRO & $0.5 \% \mathrm{PRO}$ & $1.0 \%$ PRO & SEM & $\mathrm{p}$ value \\
\hline Average daily gain (ADG, g) & 439 & 457 & 412 & 20 & 0.15 \\
\hline Average daily feed intake (ADFI, g) & 725 & 716 & 689 & 38 & 0.48 \\
\hline Feed:gain (F/G) & 1.65 & 1.57 & 1.67 & 0.11 & 0.76 \\
\hline
\end{tabular}

PRO, proline; SEM, standard error of the mean.

${ }^{1}$ Values are means for twelve pigs (two pigs per replicate).

Table 3. Effects of L-proline supplementation on growth performance of weanling piglets after LPS challenge or saline injection (10-20 d) ${ }^{1}$

\begin{tabular}{|c|c|c|c|c|c|c|c|c|c|c|}
\hline \multirow{2}{*}{ Items } & \multicolumn{3}{|c|}{- LPS } & \multicolumn{3}{|c|}{ +LPS } & \multirow{2}{*}{$\begin{array}{c}\text { Pooled } \\
\text { SEM }\end{array}$} & \multicolumn{3}{|c|}{$p$ value } \\
\hline & $0 \% \mathrm{PRO}$ & $0.5 \%$ PRO & $1.0 \%$ PRO & $0 \%$ PRO & $0.5 \%$ PRO & $1.0 \% \mathrm{PRO}$ & & LPS & PRO & LPS $\times$ PRO \\
\hline $\mathrm{ADG}(\mathrm{g})$ & 476 & 552 & 472 & 418 & 452 & 419 & 10 & 0.003 & 0.088 & 0.64 \\
\hline ADFI (g) & 960 & 1020 & 926 & 825 & 850 & 795 & 52 & 0.004 & 0.547 & 0.71 \\
\hline $\mathrm{F} / \mathrm{G}$ & 2.02 & 1.85 & 1.96 & 1.99 & 1.88 & 1.90 & 0.19 & 0.92 & 0.88 & 0.44 \\
\hline
\end{tabular}

LPS, lipopolysaccharide; PRO, proline; SEM, standard error of the mean; ADG, average daily gain; ADFI, average daily feed intake; F/G, feed:gain ration.

${ }^{1}$ Lipopolysaccharide was injected on $\mathrm{d} 10$ and 20. Values are means for six pigs (one pig per replicate).

EGF and INS concentrations on $\mathrm{d} 20(\mathrm{p}<0.05)$. There was LPS challengexproline interaction for GH concentrations on $\mathrm{d} 10 \quad(\mathrm{p}<0.05)$. When no LPS challenge, dietary supplementation with $1.0 \%$ proline had no effect on the GH concentrations on $\mathrm{d} 10(\mathrm{p}>0.05)$, but could decrease it after LPS challenge $(p<0.05)$. Dietary supplementation with $1.0 \%$ proline could decrease glucagon concentration on $\mathrm{d}$ 10 after LPS challenge $(\mathrm{p}<0.05)$.

Plasma malondialdehyde content and activities of catalase and superoxide dismutase

As shown in Table 5, dietary supplementation with proline could increase SOD activity significantly on d 10 and $20(p<0.05)$ in both saline-treated and LPS-challenged pigs. There was no LPS challengexproline interaction for CAT, MDA, and SOD ( $\mathrm{p}<0.05)$.

\section{Plasma heat shock proteins-70 and $\alpha 1$-acid glycoprotein concentrations}

Plasma HSP-70 and $\alpha 1$-AGP concentrations were shown in Table 6. Dietary supplementation with $1.0 \%$ proline could increase HSP-70 concentration on d 10 in both saline-treated and LPS-challenged pigs $(\mathrm{p}<0.05)$. There was no LPS challenge $\times$ proline interaction for $\alpha 1$ AGP and HSP-70 concentrations on d 10 and d 20 (p>0.05).

\section{Plasma diamine oxidase, D-xylose, nitric oxide synthase, and NOx concentrations}

Plasma DAO, D-xylose, NOS and NOx concentrations were summarized in Table 7. LPS challenge could decrease D-xylose concentrations on d 20, and NOS concentrations on d $10(\mathrm{p}<0.05)$. Proline supplementation had no effect on DAO concentrations, however, after LPS challenge, it could increase DAO concentrations $(\mathrm{p}<0.05)$. There was LPS

Table 4. Effects of L-proline supplementation on hormone concentrations in plasma of weanling piglets after LPS challenge (10-20 d) ${ }^{1}$

\begin{tabular}{|c|c|c|c|c|c|c|c|c|c|c|c|}
\hline \multirow{2}{*}{ Items } & \multirow{2}{*}{ Day } & \multicolumn{3}{|c|}{-LPS } & \multicolumn{3}{|c|}{$+\mathrm{LPS}$} & \multirow{2}{*}{$\begin{array}{c}\text { Pooled } \\
\text { SEM }\end{array}$} & \multicolumn{3}{|c|}{$\mathrm{p}$ value } \\
\hline & & $0 \% \mathrm{PRO}$ & $0.5 \%$ PRO & $1.0 \%$ PRO & $0 \%$ PRO & $0.5 \%$ PRO & $1.0 \%$ PRO & & LPS & PRO & LPS $\times$ PRO \\
\hline \multirow[t]{2}{*}{$\mathrm{EGF}(\mathrm{U} / \mathrm{mL})$} & 10 & 1.29 & 1.21 & 1.27 & 1.02 & 1.50 & 1.14 & 0.058 & 0.73 & 0.28 & 0.087 \\
\hline & 20 & 1.44 & 1.67 & 1.80 & 1.1 & 1.23 & 1.12 & 0.062 & 0.001 & 0.28 & 0.42 \\
\hline \multirow[t]{2}{*}{ IGF-1 (ng/mL) } & 10 & 218.77 & 212 & 223 & 240 & 254 & 219 & 7.43 & 0.139 & 0.735 & 0.333 \\
\hline & 20 & 224 & 193 & 239 & 237 & 225 & 202 & 9.66 & 0.875 & 0.609 & 0.307 \\
\hline \multirow[t]{2}{*}{$\mathrm{GH}(\mathrm{ng} / \mathrm{mL})$} & 10 & $4.87^{\mathrm{ab}}$ & $4.38^{\mathrm{ab}}$ & $5.38^{\mathrm{a}}$ & $4.60^{\mathrm{ab}}$ & $5.26^{\mathrm{ab}}$ & $4.27 \mathrm{~b}$ & 0.19 & 0.607 & 0.970 & 0.048 \\
\hline & 20 & 5.19 & 5.17 & 5.11 & 5.59 & 5.24 & 4.32 & 0.11 & 0.731 & 0.151 & 0.211 \\
\hline \multirow[t]{2}{*}{ Glucagon (pg/mL) } & 10 & 103 & 125 & 104 & 126 & 128 & 92 & 5.45 & 0.61 & 0.031 & 0.25 \\
\hline & 20 & 99.9 & 92.2 & 101 & 75.8 & 110 & 103 & 6.21 & 0.93 & 0.40 & 0.20 \\
\hline \multirow[t]{2}{*}{ INS (U/mL) } & 10 & 10.2 & 13.2 & 10.1 & 13.0 & 12.5 & 10.0 & 0.65 & 0.51 & 0.084 & 0.31 \\
\hline & 20 & 8.55 & 11.7 & 8.60 & 6.82 & 8.48 & 8.03 & 0.38 & 0.046 & 0.08 & 0.47 \\
\hline
\end{tabular}

LPS, lipopolysaccharide; PRO, proline; SEM, standard error of the mean; EGF, epidermal growth factor; IGF-I, insulin-like growth factor 1; GH, growth hormone; INS, insulin.

${ }^{1}$ Lipopolysaccharide was administered on d 10 and 20. Values are means for six pigs (one pig per replicate).

Means in a row with different letters differ significantly $(\mathrm{p}<0.05)$. 
Table 5. Effects of L-proline supplementation on MDA content and activities of CAT and SOD of weanling piglets after LPS challenge $(10-20 \mathrm{~d})^{1}$

\begin{tabular}{|c|c|c|c|c|c|c|c|c|c|c|c|}
\hline \multirow{2}{*}{ Items } & \multirow{2}{*}{ Day } & \multicolumn{3}{|c|}{$-\mathrm{LPS}$} & \multicolumn{3}{|c|}{$+\mathrm{LPS}$} & \multirow{2}{*}{$\begin{array}{c}\text { Pooled } \\
\text { SEM }\end{array}$} & \multicolumn{3}{|c|}{$\mathrm{p}$ value } \\
\hline & & $0 \% \mathrm{PRO}$ & $0.5 \% \mathrm{PRO}$ & $1.0 \%$ PRO & $0 \%$ PRO & $0.5 \%$ PRO & $1.0 \%$ PRO & & LPS & PRO & LPS $\times$ PRO \\
\hline \multirow[t]{2}{*}{$\overline{\mathrm{CAT}}(\mathrm{U} / \mathrm{mL})$} & 10 & 6.25 & 7.16 & 9.09 & 7.31 & 10.5 & 9.63 & 0.67 & 0.19 & 0.20 & 0.63 \\
\hline & 20 & 4.09 & 4.65 & 2.55 & 3.64 & 3.06 & 3.29 & 0.38 & 0.58 & 0.51 & 0.46 \\
\hline \multirow[t]{2}{*}{$\operatorname{MDA}(\mathrm{nmol} / \mathrm{mL})$} & 10 & 10.5 & 11.1 & 5.54 & 9.05 & 8.23 & 8.42 & 0.61 & 0.67 & 0.103 & 0.129 \\
\hline & 20 & 7.33 & 12.0 & 8.62 & 9.24 & 9.27 & 10.61 & 0.89 & 0.78 & 0.44 & 0.34 \\
\hline \multirow[t]{2}{*}{$\mathrm{SOD}(\mathrm{U} / \mathrm{mL})$} & 10 & 138 & 156 & 174 & 139 & 155 & 149 & 4.06 & 0.13 & 0.004 & 0.11 \\
\hline & 20 & 149 & 154 & 151 & 148 & 162 & 155 & 1.71 & 0.16 & 0.025 & 0.47 \\
\hline
\end{tabular}

MDA, Malondialdehyde; CAT, catalase; SOD, superoxide dismutase; LPS, lipopolysaccharide; PRO, proline; SEM, standard error of the mean.

${ }^{1}$ Lipopolysaccharide was administered on d 10 and 20. Values are means for six pigs (one pig per pen).

Table 6. Effects of L-proline supplementation on plasma a1-AGP, and HSP-70 concentration of weanling piglets after LPS challenge $(10-20 \mathrm{~d})^{1}$

\begin{tabular}{|c|c|c|c|c|c|c|c|c|c|c|c|}
\hline \multirow{2}{*}{ Items } & \multirow{2}{*}{ Day } & \multicolumn{3}{|c|}{-LPS } & \multicolumn{3}{|c|}{ +LPS } & \multirow{2}{*}{$\begin{array}{c}\text { Pooled } \\
\text { SEM }\end{array}$} & \multicolumn{3}{|c|}{$p$ value } \\
\hline & & $0 \%$ PRO & $0.5 \%$ PRO & $1.0 \%$ PRO & $0 \%$ PRO & $0.5 \%$ PRO & $1.0 \%$ PRO & & LPS & PRO & $\mathrm{LPS} \times \mathrm{PRO}$ \\
\hline$\alpha 1-A G P$ & 10 & 309 & 470 & 283 & 383 & 375 & 383 & 47.62 & 0.76 & 0.64 & 0.58 \\
\hline$(\mu \mathrm{g} / \mathrm{mL})$ & 20 & 187 & 206 & 237 & 187 & 197 & 278 & 15.51 & 0.72 & 0.16 & 0.79 \\
\hline HSP-70 & 10 & 7.15 & 8.98 & 9.32 & 6.89 & 9.25 & 9.89 & 0.52 & 0.82 & 0.048 & 0.92 \\
\hline$(\mathrm{ng} / \mathrm{mL})$ & 20 & 10.08 & 9.34 & 11.48 & 8.80 & 10.24 & 8.83 & 0.44 & 0.22 & 0.67 & 0.20 \\
\hline
\end{tabular}

11-AGP, $\alpha 1$-acid glycoprotein; HSP-70, heat shock proteins-70; LPS, lipopolysaccharide; PRO, proline; SEM, standard error of the mean.

${ }^{1}$ Lipopolysaccharide was administered on d 10 and 20. Values are means for six pigs (one pig per pen).

challengexproline interaction for DAO $(\mathrm{p}<0.05)$. Dietary supplementation with $1.0 \%$ proline could increase the Dxylose level when no LPS challenge $(\mathrm{p}<0.05)$.

\section{DISCUSSION}

Just like many previous studies, results of our study also demonstrated that both ADG and ADFI decreased after LPS challenge, which likely resulted from the impaired intestinal and immune functions (Wang et al., 2008). In this study, dietary supplementation with proline had a tendency to increase ADG, indicating a beneficial effect of supplemental appropriate proline on growth performance in piglet. However, Samuels (1989) reported that dietary supplementation with $1.0 \%$ to $1.5 \%$ proline had no effect on the performance in piglets from 1 to $10 \mathrm{~d}$ of age, suggesting that the requirement of proline in neonatal pig might be more than in young pigs.

Epidermal growth factor (EGF) is a 53-amino acid single-chain polypeptide. Its role in stimulating intestinal epithelium proliferation, differentiation, and intestinal maturation has been documented (Dignass and Sturm, 2001). Previous studies had reported that LPS induced the release of EGF (Ohyama et al., 2001). However, in the present study, LPS challenge had no effect on its concentration. Dietary supplementation with $0.5 \%$ proline had a tendency to increase EGF concentration after LPS challenge, which indicated that LPS challenge might provide a potential function to mobilize proline, which then stimulated EGF secretion to alleviate the LPS stress.

Table 7. Effects of L-proline supplementation on plasma D-xylose, DAO, NOx, and NOS concentration in weanling piglets after LPS challenge $(10-20 \mathrm{~d})^{1}$

\begin{tabular}{|c|c|c|c|c|c|c|c|c|c|c|c|}
\hline \multirow{2}{*}{ Items } & \multirow{2}{*}{ Day } & \multicolumn{3}{|c|}{-LPS } & \multicolumn{3}{|c|}{ +LPS } & \multirow{2}{*}{$\begin{array}{l}\text { Pooled } \\
\text { SEM }\end{array}$} & \multicolumn{3}{|c|}{$\mathrm{p}$ value } \\
\hline & & $0 \%$ PRO & $0.5 \%$ PRO & $1.0 \%$ PRO & $0 \%$ PRO & $0.5 \%$ PRO & $1.0 \%$ PRO & & LPS & PRO & LPS $\times$ PRO \\
\hline$\overline{\mathrm{DAO}}(\mathrm{U} / \mathrm{mL})$ & 20 & $39.3^{\mathrm{ab}}$ & $28.9^{\mathrm{a}}$ & $46.0^{\mathrm{b}}$ & $29.67^{\mathrm{a}}$ & $46.4^{\mathrm{b}}$ & $47.6^{\mathrm{b}}$ & 2.02 & 0.40 & 0.027 & 0.024 \\
\hline $\begin{array}{l}\text { D-xylose } \\
(\mathrm{mmol} / \mathrm{L})\end{array}$ & 20 & 0.49 & 0.56 & 0.67 & 0.39 & 0.35 & 0.49 & 0.02 & 0.002 & 0.05 & 0.61 \\
\hline NOS & 10 & 27.9 & 25.4 & 24.9 & 21.1 & 16.1 & 21.8 & 1.11 & 0.005 & 0.32 & 0.49 \\
\hline$(\mathrm{U} / \mathrm{mL})$ & 20 & 23.7 & 21.7 & 20.8 & 19.7 & 21.9 & 24.5 & 0.89 & 0.97 & 0.86 & 0.14 \\
\hline NO & 10 & 224 & 232 & 172 & 162 & 240 & 172 & 15.09 & 0.53 & 0.20 & 0.55 \\
\hline$(\mu \mathrm{mol} / \mathrm{L})$ & 20 & 207 & 255 & 182 & 215 & 385 & 194 & 14.39 & 0.43 & 0.21 & 0.67 \\
\hline
\end{tabular}

DAO, diamine oxidase; NOS, total NO synthase; NO, nitric oxide; LPS, lipopolysaccharide; PRO, proline; SEM, standard error of the mean

${ }^{1}$ Lipopolysaccharide was administered on $\mathrm{d} 10$ and 20. Values are means for six pigs (one pig per pen).

Means in a row with different letters differ significantly $(\mathrm{p}<0.05)$. 
Growth hormone-IGF-I axis plays a major role in growth regulation. Soto et al. (1998) reported that the decrease in GH and IGF-I secretion was important mechanism in BW loss during chronic inflammation. In our study, we found that $1.0 \%$ proline could decrease GH level after LPS challenge, and there was a interaction between proline and LPS-challenge, which indicated that proline supplementation could affected GH concentration just under the LPS challenge conditions. The results were also consistent with the ADG results.

Oxidative stress is one of the major factors that impair the integrity of the gastrointestinal tract barrier and increase intestinal permeability (Kaplan et al., 2007). Antioxidant enzymes are an important part of the antioxidant system, and the antioxidant system in the body can be assessed by the determination of antioxidant enzyme activities (Buonocore and Groenendaal, 2007). Antioxidant enzymes, including CAT and SOD, require dietary supplies of the appropriated nutrients. Roecker et al. (2012) reported that acute administration of proline reduced CAT and increased SOD activities, while chronic treatment increased the activities of CAT and SOD in erythrocytes in the plasma of rats. In agreement with these findings, we found proline could increase SOD activity in piglets, with or without an LPS challenge. However, we found that proline had no effect on CAT activity.

The AGP level is an indicator of the immune or physiological status (Sorrells et al., 2006). Its serum concentration has often been used as a marker of disease. Activation of the immune system, such as inflammation, tissue injury, and infection, is associated with the release of acute phase proteins by the liver, known as the acute phase response (Suffredini et al., 1999). Heat shock proteins 70 can act as a biomarker of oxidative injury (EI GolliBennour and Bacha, 2011), plays essential roles in protein metabolism and stimulate cell-mediated immunity (Moroi et al., 2000). In our study, LPS challenge had no effect on a1-AGP and HSP70 concentration, however, dietary supplementation with $1.0 \%$ proline could increase HSP-70 concentration on d 10 in both saline-treated and LPSchallenged pigs, which indicated that proline could stimulate immunity response in early weaned pigs.

D-xylose, a pentose sugar, is absorbed from the upper small intestinal tract. It is poorly metabolized by the body and has been widely applied for the investigation of small intestinal absorption (Gyr et al., 1974). In the present study, proline supplementation could increase D-xylose concentration indicating that proline could have a positive effect on the gastrointestinal tract digestibility. The activity of the DAO is so high in the intestinal mucosa, that plasma DAO activity may be useful for monitoring and evaluating gastrointestinal tract injury (Namikawa et al., 2012). In the present study, $0.5 \%$ proline supplementation decreased DAO concentrations, however, it could increase DAO concentrations after LPS challenge, which suggested that proline has a positive effect on maintenance of the mucosal barrier after LPS challenge.

\section{CONCLUSION}

Proline supplementation could improve growth performance, increase SOD activities, and has a positive effect on the gastrointestinal tract digestibility in early weaned pigs. These results indicated that exogenous proline should be appropriate to add in the early weaned pigs' diets in order to achieve better growth performance.

\section{ACKNOWLEDGMENTS}

This research was jointly supported by National Basic Research Program of China (No. 2012CB126305), Hubei Provincial Research and Development Program (No. 2010BB023), and Natural Science Foundation of Hubei Province (No. 2012FFB04805, 2011CDA131) Conflict of interest: The authors declare that they have no conflict of interest.

\section{REFERENCES}

Baker, D. H. 1977. Amino acid nutrition of the chick. In: Advances in Nutrition Research (Ed. H. H. Draper), pp. 299-335, Plenum, New York, NY, USA.

Ball, R. O., J. L. Atkinson, and H. S. Bayley. 1986. Proline as an essential amino acid for the young pig. Br. J. Nutr. 55:659-668.

Bertolo, R. F., J. A. Brunton, P. B. Pencharz, and R. O. Ball. 2003. Arginine, ornithine, and proline interconversion is dependent on small intestinal metabolism in neonatal pigs. Am. J. Physiol. Endocrinol. Metab. 284:E915-E922.

Buege, J. A. and S. D. Aust. 1978. Microsomal lipid peroxidation. Methods. Enzymol. 52:302-310.

Buonocore, G. and F. Groenendaal. 2007. Anti-oxidant strategies. Semin. Fetal Neonatal Med. 12:287-295.

Dignass, A. U. and A. Sturm. 2001. Peptide growth factors in the intestine. Eur. J. Gastroenterol. Hepatol. 13:763-770.

El Darawany, A. A. and H. M. Farghaly. 1999. Some blood biochemical as indicator to improve productive and reproductive performance in rabbit population. In: 2 . International Conference on Rabbit Production in Hot Climates (A. Testik and M. Baselga). Zaragoza: CIHEAM, p. 139-145.

El Golli-Bennour, E. and H. Bacha. 2011. Hsp70 expression as biomarkers of oxidative stress, mycotoxins' exploration. Toxicology 287:1-7.

Gyr, K., R. H. Wolf, and O. Felsenfeld. 1974. Intestinal absorption of D-xylose and folic acid in protein-deficient patas monkeys (Erythrocebus patas). Am. J. Clin. Nutr. 27:350-354.

Hosoda, N., M. Nishi, M. Nakagawa, Y. Hiramatsu, K. Hioki, and 
M. Yamamoto. 1989. Structural and functional alterations in the gut of parenterally or enterally fed rats. J. Surg. Res. 47: 129-133.

Kang, P., H. L. Xiao, Y. Q. Hou, B. Y. Ding, Y. L. Liu, H. L. Zhu, Q. Z. Hu, Y. Hu, and Y. L. Yin. 2010. Effects of astragalus polysaccharides, achyranthes bidentata polysaccharides, and acantbepanax senticosus saponin on the performance and immunity in weaned pigs. Asian Australas. J. Anim. Sci. 23: 750-756.

Kaplan, M., E. A. Mutlu, M. Benson, J. Z. Fields, A. Banan, and A. Keshavarzian. 2007. Use of herbal preparations in the treatment of oxidant-mediated inflammatory disorders. Complement. Ther. Med. 15:207-216.

Lay, D. C. Jr., H. G. Kattesh, J. E. Cunnick, M. J. Daniels, G. Kranendonk, K. A. McMunn, M. J. Toscano, and M. P. Roberts. 2011. Effect of prenatal stress on subsequent response to mixing stress and a lipopolysaccharide challenge in pigs. J. Anim. Sci. 89:1787-1794.

Mansoori, B., H. Nodeh, M. Modirsanei, S. Rahbari, and P. Aparnak. 2009. D-Xylose absorption test: A tool for the assessment of the effect of anticoccidials on the intestinal absorptive capacity of broilers during experimental coccidiosis. Anim. Feed Sci. Technol. 148:301-308.

Moroi, Y., M. Mayhew, J. Trcka, M. H. Hoe, Y. Takechi, F. U. Hartl, J. E. Rothman, and A. N. Houghton. 2000. Induction of cellular immunity by immunization with novel hybrid peptides complexed to heat shock protein 70. Proc. Natl. Acad. Sci. USA. 97:3485-3490.

Namikawa, T., I. Fukudome, H. Kitagawa, T. Okabayashi, M. Kobayashi, and K. Hanazaki. 2012. Plasma diamine oxidase activity is a useful biomarker for evaluating gastrointestinal tract toxicities during chemotherapy with oral fluorouracil anti-cancer drugs in patients with gastric cancer. Oncology 82: $147-152$.

NRC. 1998. Nutrient Requirements of Swine. 10th ed. National Academic Press, Washington, DC, USA.

Ohyama, N., H. Sato, and T. E. Tanaka. 2001. Epidermal growth factor enhances lipopolysaccharide-induced procoagulant activity on the cell surface of endothelial cells. Blood Coagul. Fibrinolysis 12:385-389.

Phang, J. M. and W. Liu. 2012. Proline metabolism and cancer. Front. Biosci. 17:1835-1845.
Roecker, R., G. M. Junges, D. D. de Lima, J. G. da Cruz, A. T. Wyse, and D. D. Dal Magro. 2012. Proline alters antioxidant enzyme defenses and lipoperoxidation in the erythrocytes and plasma of rats: in vitro and in vivo studies. Biol. Trace Elem. Res. 147:172-179.

Samuels, S. E., H. L. Aarts, and R. O. Ball. 1989. Effect of dietary proline on proline metabolism in the neonatal pig. J. Nutr. 119: 1900-1906.

Sorrells, A. D., S. D. Eicher, K. A. Scott, M. J. Harris, E. A. Pajor, D. C. Jr. Lay, and B. T. Richert. 2006. Postnatal behavioral and physiological responses of piglets from gilts housed individually or in groups during gestation. J. Anim. Sci. 84: 757-766.

Soto, L., A. I. Martín, S. Millán, E. Vara, and A. López-Calderón. 1998. Effects of endotoxin lipopolysaccharide administration on the somatotropic axis. J. Endocrinol. 159:239-246.

Suffredini, A. F., G. Fantuzzi, R. Badolato, J. J. Oppenheim, and N. P. O'Grady. 1999. New insights into biology of the acute phase response. J. Clin. Immunol. 19:203-214.

Wang, J., L. Chen, P. Li, X. Li, H. Zhou, F. Wang, D. Li, Y. Yin, and G. Wu. 2008. Gene expression is altered in piglets small intestine by weaning and dietary glutamine supplementation. J. Nutr. 138:1025-1032.

Wei, J. W., R. J. Carroll, K. K. Harden, and G. Wu. 2012. Comparisons of treatment means when factors do not interact in two-factorial studies. Amino Acids 42:2031-2035.

Wu, G. 1997. Synthesis of citrulline and arginine from proline in enterocytes of postnatal pigs. Am. J. Physiol. Gastrointest. Liver Physiol. 272:G1382-1390.

Wu, G., D. A. Knabe, N. E. Flynn, W. Yan, and S. P. Flynn. 1996. Arginine degradation in developing porcine enterocytes. Am. J. Physiol. Gastrointest. Liver. Physiol. 271:G913-G919.

Wu, G., F. W. Bazer, R. C. Burghardt, G. A. Johnson, S. W. Kim, D. A. Knabe, P. Li, X. Li, J. R. McKnight, M. C. Satterfield, and T. E. Spencer. 2011. Proline and hydroxyproline metabolism: implications for animal and human nutrition. Amino Acids 40: 1053-1063.

Wu, G., F. W. Bazer, S. Datta, G. A. Johnson, P. Li, M. C. Satterfield, and T. E. Spencer. 2008. Proline metabolism in the conceptus: implications for fetal growth and development. Amino Acids 35:691-702.

Wu, G. Y., N. E. Flynn, and D. A. Knabe. 2000. Enhanced intestinal synthesis of polyamines from proline in cortisoltreated piglets. Am. J. Physiol. Endocrinol. Metab. 279:E395E402. 